\title{
Iron status and diet at two years of age: a longitudinal study of healthy Norwegian and immigrant children
}

\author{
By Ronnaug Aa. Fagerli, Margareta Wandel, Petra Turet Olsen, \\ Johan Ek, Ketil Thorstensen, Ole-Lars Brekke and Berit Borch-Iohnsen \\ Received November 14, 1995; Accepted February 23, 1996
}

\begin{abstract}
Summary
This paper reports the results from a longitudinal study on iron status and diet among Norwegian and immigrant children living in the same residential area. This was the second part of the study and the children were two years old.

All mothers with a normal pregnancy and delivery were invited to participate, and 80 of 95 eligible, accepted. Iron status analyses were carried out for 78 healthy children; 37 Norwegians and 41 immigrants ( 20 of Turkish origin).

More immigrant children had depleted iron stores, compared to Norwegians. The median values for haemoglobin $(\mathrm{Hb})$, mean corpuscular volume (MCV), mean corpuscular haemoglobin $(\mathrm{MCH})$, serum ferritin (SF), transferrin saturation (TfS), free erythrocyte protoporphyrin (FEP) and transferrin receptor (TfR) were all within normal ranges. The differences between immigrants and Norwegians were significant except for $\mathrm{Hb}$ and SF. There was a rise in MCV and TfS and a decline in TfR among both Norwegian and immigrant children from one to two years, and a decline in SF among the Norwegians.

The Norwegian children had a higher intake of soft drinks, dark bread and different iron-rich bread spreads than the immigrants, who had a higher intake of orange juice, and a more frequent use of citrus fruits than the Norwegians.

Milk intake was negatively related - and consumption frequency of brown whey cheese was positively related - to iron stores indicated by SF values above or below $15 \mu \mathrm{g} / \mathrm{L}$.

The results suggest that differences in food intake may explain the lower iron status in immigrants compared to Norwegians. More attention should be directed to children's diet and iron status in the second and probably third years of life.
\end{abstract}

\section{Sammendrag \\ Jernstatus og kosthold ved to ärs alder: en longitudinell studie på friske norske barn og barn med innvandrerbakgrunn} Dette er andre del av en longitudinell studie om jernstatus og kosthold blant friske norske barn og barn med innvandrerbakgrunn som bor i samme geografiske område. I den første delen (ved ett års alder) fant vi at innvandrerbarn hadde lavere jernstatus enn norske barn, og at visse aspekter ved kostutviklingen og kostholdet ved ett års alder muligens kan forklare dette. Målet med denne delen av studien var å se om det var forskjeller i jernstatus ved to år; å belyse endring $\mathrm{i}$ jernstatus fra ett til to års alder; og å belyse aspekter ved kostholdet som kan ha betydning for jernstatus. Alle barn født etter et normalt svangerskap ble invitert til å delta og 80 av 95 tilgjengelige mødre sa ja; 78 barn oppfylte kriteriene (klinisk friske og CRP $(\leq 15 \mathrm{mg} / \mathrm{L})$ for å delta i jernstatus-analysene; 37 norske og 41 innvandrere hvorav 20 var tyrkiske. Det var en tendens til at flere innvandrerbarn enn norske barn hadde tomme jernlagre $(\mathrm{p}=0.07)$. Medianverdiene for $\mathrm{Hb}, \mathrm{MCV}, \mathrm{MCH}, \mathrm{SF}$, TfS, og for FEP og TfR var innefor normalområdet. Forskjellen mellom innvandrere og norske var signifikante med unntak av verdien for $\mathrm{Hb}$ og SF.

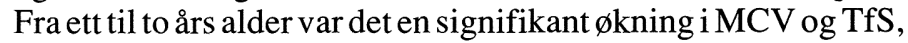
senkning i TfR både blant norske og innvandrere, og en tendens til senkning i serum ferritin $(\mathrm{p}=0.06)$ blant norske barn. Ved to års alder hadde de norske barna et $h \varnothing$ yere inntak av leskedrikker, grovbrød og forskjellige jernholdige pålegg, mens innvandrerbarna (og de tyrkiske) hadde høyere inntak av appelsinjuice, og hyppigere inntak av bl.a. sitrusfrukter. Inntaket av melk var negativt relatert og inntaket av brunost var positivt relatert til jernlagrene ( $\mathrm{SF}$ over eller under $15 \mu \mathrm{g} / \mathrm{L}$ ) $\mathrm{i}$ en logistisk regresjonsmodell.

\section{Introduction}

Infants and young children are at especially high risk of developing iron deficiency because of high requirements corresponding to basal losses, expansion of red cell mass and rapid growth of body tissues (1). The health implications of poor iron status in early childhood have lately acquired renewed attention among nutritional scientists. There are indications that iron deficiency anaemia, may inhibit the mental

Rønnaug Aa. Fagerli, Cand. scient. and Berit BorchIohnsen, Ph.D., Nordic School of Nutrition, University of Oslo, Margareta Wandel, Ph.D., Institute for Consumer Research, Lysaker, Petra Turet Olsen MD., Fjell Health Clinic, Drammen, Johan Ek, MD. Ph.D., Department of Pediatrics, Buskerud Central Hospital, Drammen, Ketil Thorstensen, Ph.D. and Ole-Lars Brekke, MD., Ph.D., Department of Clinical Chemistry, University Hospital, Trondheim.

Correspondence: Berit Borch-Iohnsen, Nordic School of Nutrition, Univ of Oslo, POBox 1046, N-0316 Oslo. and motor development of the child (2). However, there is no general agreement as to long term implications of early iron deficiency on mental development $(3,4,5)$.

Little is known about the prevalence of iron deficiency among Norwegian children in the second year of life. The prevalence of iron deficiency and/or anaemia in Norwegian infants ( 12 months of age or less) has been steadily declining during the past two decades $(6,7,8)$. In one study the prevalence of anaemia (haemoglobin $<110$ $\mathrm{g} / \mathrm{L}$ ) was lower at two years than at one year of age (6). A more recent study showed that in a group of 44 healthy two-year old Norwegian children 16\% had anaemia, and $9 \%$ of these had iron deficiency anaemia (9).

Even less is known about the iron status of immigrant children living in Norway. A few studies have compared iron status and diet between native and immigrant children in Northern European countries. These have reported higher prevalences of anaemia among healthy immigrant children compared to groups of native children $(10,11,12)$. Immigrant children are also more often hospitalized because of anaemia than the native children in these countries $(13,14,15)$.

In the first year of life breast milk as the only food for the first four to six months, and thereafter gradually weaning to complementary foods which are rich in iron, or which may enhance iron absorption is recommended in Norway (16). A critical period may arise when the child is introduced to the ordinary family diet (17). Partaking in the family meals does not necessarily mean that the child receives a more varied and nutritious diet than before. Scandinavian studies suggest that this die- 
tary shift may entail an increase in the intake of fat and sugar $(17,18)$. In one study of two-year-old healthy Norwegian children, sugar accounted for median $17 \%$ of the energy in the diet (9). Food items with a high proportion of fat and sugar may influence iron status in a negative way since they often contain inadequate amounts of iron for a given energy intake. In some studies a high intake of milk has been seen to correlate with iron deficiency (13).

Our study has a longitudinal design, ie., the same children are examined at one, two and four years of age.

The entire study has been performed at one primary health clinic in Norway, located in an area with a large immigrant population, particularly of Turkish origin. The longitudinal design gives the opportunity to follow the dietary changes and to discuss these changes in relation to iron status over an extended period of time. Such data are necessary as a background for dietary advice appropriate to different age- and cultural groups.

In the first part of the study we examined weaning practices, food intake and iron status among one-year-old healthy Norwegian infants and infants of immigrant descent, living in the same residential area in Norway (19). The results indicated lower iron status among immigrant infants than among Norwegian infants and there were differences in the weaning practices (lenght of breast feeding, introduction of formula and cow milk) and in the use of certain foods, which may explain the differences in iron status.

The present paper reports the results when the children were two years old. The specific aims of this part of the study were to find out: 1 ) if the immigrant children still had lower values than the Norwegians in terms of indicators for iron status, 2) if children with iron deficiency at one year were more prone to be iron deficient at two years of age, and 3 ) if there were aspects of the diet which may explain possible differences in the prevalence of iron deficiency in two-year-old children:

\section{Materialandmethods}

\section{Sample}

The population included two-year-old healthy children ( 2 years \pm 1 month). The children were first enrolled to the study when they were brought to health control at one year of age at Fjell Health Clinic in Drammen, Norway. When the children were two years of age, 80 of 95 eligible mothers accepted to participate in the second part of the study.

Blood samples were obtained from 80 children. Two of these were excluded from the biochemical analyses because of signs of infection (C-reactive protein

Table 1. Iron status at two years of age.

\begin{tabular}{|c|c|c|c|c|c|c|}
\hline \multirow[t]{2}{*}{ Parameter } & \multicolumn{2}{|c|}{ Norwegian } & \multicolumn{2}{|c|}{ Immigrants } & \multicolumn{2}{|c|}{ Turkish } \\
\hline & $\mathrm{n}$ & $\begin{array}{l}\text { median } \\
(95 \% \text { c.i. })\end{array}$ & $\mathrm{n}$ & $\begin{array}{l}\text { median } \\
(95 \% \text { c.i. })\end{array}$ & $\mathrm{n}$ & $\begin{array}{l}\text { median } \\
(95 \% \text { c.i. })\end{array}$ \\
\hline $\mathrm{Hb} \quad \mathrm{g} / \mathrm{L}$ & 37 & $\begin{array}{l}118 \\
(117-120)\end{array}$ & 37 & $\begin{array}{l}118 \\
(115-122)\end{array}$ & 16 & $\begin{array}{l}121 \\
(117-125)\end{array}$ \\
\hline MCV fl. & 37 & $\begin{array}{l}80.0 \\
(79.0-82.0)\end{array}$ & 37 & $\begin{array}{l}76.0^{\mathrm{a}} \\
(74.0-78.5)\end{array}$ & 16 & $\begin{array}{l}75.5^{\mathrm{a}} \\
(74.5-78.5)\end{array}$ \\
\hline $\mathrm{MCH}$ pg & 37 & $\begin{array}{l}26.2 \\
(25.7-26.6)\end{array}$ & 37 & $\begin{array}{l}24.8^{b} \\
(23.8-25.5)\end{array}$ & 16 & $\begin{array}{l}24.9^{\mathrm{e}} \\
(24.0-26.4)\end{array}$ \\
\hline$\mu \mathrm{g} / \mathrm{L}$ & 35 & $\begin{array}{l}17.0 \\
(15.5-23,0)\end{array}$ & 37 & $\begin{array}{l}17.0 \\
(14.5-24.0)\end{array}$ & 16 & $\begin{array}{l}18.0 \\
(13.5-25.5)\end{array}$ \\
\hline FEP $\mu \mathrm{mol} / \mathrm{LRBC}$ & 27 & $\begin{array}{l}0.61 \\
(0.51-0.69)\end{array}$ & 26 & $\begin{array}{l}0.83^{c} \\
(0.67-0.97)\end{array}$ & 11 & $\begin{array}{l}0.82^{\mathrm{e}} \\
(0.55-1.1)\end{array}$ \\
\hline $\mathrm{TfR} \quad \mathrm{mg} / \mathrm{L}$ & 35 & $\begin{array}{l}2.75 \\
(2.7-3.0)\end{array}$ & 36 & $\begin{array}{l}3.1^{\mathrm{c}} \\
(2.9-3.3)\end{array}$ & 15 & $\begin{array}{l}3.1 \\
(2.8-3.2)\end{array}$ \\
\hline TfS $\%$ & 34 & $\begin{array}{l}21.7 \\
(18.9-26.9)\end{array}$ & 37 & $\begin{array}{l}16.1^{\mathrm{d}} \\
(13.8-23.5)\end{array}$ & 16 & $\begin{array}{l}20.6 \\
(15.3-27.6)\end{array}$ \\
\hline
\end{tabular}

${ }^{\mathrm{a}} \mathrm{p}<0.001,{ }^{\mathrm{b}} \mathrm{p}<0.01,{ }^{\mathrm{c}} \mathrm{p}<0.05,{ }^{\mathrm{d}} \mathrm{p}=0.07,{ }^{\mathrm{e}} \mathrm{p}=0.08$

Mann-Whitney test, different from Norwegians.

values $(\mathrm{CRP})>15 \mathrm{mg} / \mathrm{L})$. The resulting 78 children included 37 Norwegians and 41 from immigrant families. Twenty of the immigrant children were of Turkish origin. The others were of Vietnamese $(n=7)$, Pakistani $(n=5)$, and a few of origin from other countries $(n=9)$. Children of mixed marriages with Norwegian mother were classified as Norwegian ( $n=4)$.

When testing for association between diet and iron status, six children were excluded due to use of iron supplements at two years of age.

\section{Haematological tests \\ and serum analyses}

The same tests were performed at one and two years of age (19). Venous blood samples were obtained before 12 am and haematological tests were carried out within 6 hours. These were haemoglobin $(\mathrm{Hb})$, mean corpuscular volume (MCV) and mean corpuscular haemoglobin $(\mathrm{MCH})$. Serum samples were stored at $-40^{\circ} \mathrm{C}$, and all samples were analyzed at the end of the study. Serum ferritin (SF), serum transferrin and serum iron for calculation of transferrin saturation (TfS), serum transferrin receptor (TfR) and free erythrocyte protoporphyrin (FEP) were analyzed as previously described (19). CRP was analyzed to exclude children with mild infections. The following cut off points for anaemia or iron deficiency were used: $\mathrm{Hb}$ $<110 \mathrm{~g} / \mathrm{L}, \mathrm{MCV}<72 \mathrm{fl}, \mathrm{MCH}<24 \mathrm{pg}$, TfS $<12 \%, \mathrm{FEP}>1.42 \mu \mathrm{mol} / \mathrm{L} \mathrm{RBC}$ and SF $<10 \mu \mathrm{g} / \mathrm{L}(20)$. Indicators for depleted, very low and low iron stores were $\mathrm{SF}<10$ $\mu \mathrm{g} / \mathrm{L},<15 \mu \mathrm{g} / \mathrm{L}$ and $<20 \mu \mathrm{g} / \mathrm{L}$, respectively. The cut off point for TfR was set at $>3.6 \mathrm{mg} / \mathrm{L}$ according to a method recommended by Olivares et al (21). Iron deficiency anaemia was defined as $\mathrm{Hb}<110$ $\mathrm{g} / \mathrm{L}$ and $\mathrm{SF}<15 \mu \mathrm{g} / \mathrm{L}$ according to a recent recommendation from the US National Academy of Science (22).

\section{Dietaryinterviews}

Dietary interviews were carried out according to a questionnaire, with questions about length of breastfeeding, time of introduction and lenght of use of weaning foods, such as cow milk, formula milk, and infant cereals, as well as number of meals and inbetween eating events per day. The questionnaire also included questions about frequency of use of certain foods important with regard to iron intake and absorption constructed to suit the age group and the ethnical background of the children. Different parameters of the diet were selected, either because they are particularly rich or poor sources of iron, or have an enhancing vs. inhibiting effect on iron absorption. We applied the same questionnaire at one and two years of age except that in the present questionnaire questions about the amount of milk, soft-drinks, fruit juices, bread and certain bread spreads and bread cuts taken per day were formulated so that the amounts eaten could be estimated from cup/glass sizes, eg., small cup $=100 \mathrm{ml}$ and large cup $=200 \mathrm{ml}$. The interviews were carried out by the same primary health care nurse at both ages. Interviews with non-Norwegian speaking 
Table 2. Number of children below cut off points for serum ferritin and haemoglobin at two years of age.

\begin{tabular}{|c|c|c|c|c|c|c|}
\hline \multirow[t]{2}{*}{ Indicators } & \multicolumn{2}{|c|}{ Norwegian } & \multicolumn{2}{|c|}{ Immigrants } & \multicolumn{2}{|c|}{ Turkish } \\
\hline & $\mathrm{n}$ & $\%$ & $\mathrm{n}$ & $\%$ & $\mathrm{n}$ & $\%$ \\
\hline \multicolumn{7}{|l|}{ Serumferritin } \\
\hline$<10 \mu \mathrm{g} / \mathrm{L}$ & 3 & 9 & 9 & $24^{\mathrm{a}}$ & 3 & 19 \\
\hline$<15 \mu \mathrm{g} / \mathrm{L}$ & 11 & 32 & 13 & 35 & 6 & 38 \\
\hline$<20 \mu \mathrm{g} / \mathrm{L}$ & 23 & 66 & 21 & 57 & 9 & 56 \\
\hline total $n$ & 37 & & 37 & & 16 & \\
\hline \multicolumn{7}{|l|}{ Haemoglobin } \\
\hline$<110 \mathrm{~g} / \mathrm{L}$ & 2 & 5 & 6 & 16 & 1 & 6 \\
\hline total n & 37 & & 37 & & 16 & \\
\hline \multicolumn{7}{|l|}{ Iron deficiency } \\
\hline \multicolumn{7}{|l|}{ anaemia } \\
\hline \multicolumn{7}{|l|}{$\mathrm{Hb}<110 \mathrm{~g} / \mathrm{L}$} \\
\hline$+\mathrm{SF}<15 \mu \mathrm{g} / \mathrm{L}$ & 0 & 0 & 3 & $8^{b}$ & 0 & 0 \\
\hline total $n$ & 37 & & 37 & & 16 & \\
\hline
\end{tabular}

${ }^{\mathrm{a}} \mathrm{p}=0.07,{ }^{\mathrm{b}} \mathrm{p}=0.08$ Chi square, different from Norwegians

mothers were carried out with the assistance of an interpreter.

\section{Dataanalyses}

Food indexes were modified after a method described by Bærug (8) in order to group the children into small, medium or large consumers of the following items: 1 ) Vitamin C-index from the following variables: the amounts of intake of orange juice, frequency of citrus fruits, green leafy vegetables and legumes; 2) Sugar-index from the amounts of soft drinks, frequency of sweets, bisquits/cookies, jam/marmalade and whether or not tea was sweetened; 3 ) Fat-index from the amounts of whole milk, yoghurt, fat on bread and frequency of intake of crisps; 4) Iron-index from a combination of amounts of iron received from bread and porridges with different frequencies of intake of meat and/or entrails for dinner. In order to construct the indexes, each variable mentioned above was first dichotomized; intake above or below a cut off point. The cut offs were set to have categories with approximately the same numbers of observations above and below the cut off. When summing the variables, the values 1 or 0 were given according to whether the observation was in favour of the index or not, eg., in the vitamin $\mathrm{C}$-index 1 point was given if more than $200 \mathrm{ml}$ orange juice were taken per day, and the value 0 was given if not. The

Table 3. Changes $(\Delta)$ in iron status between one and two years of age.

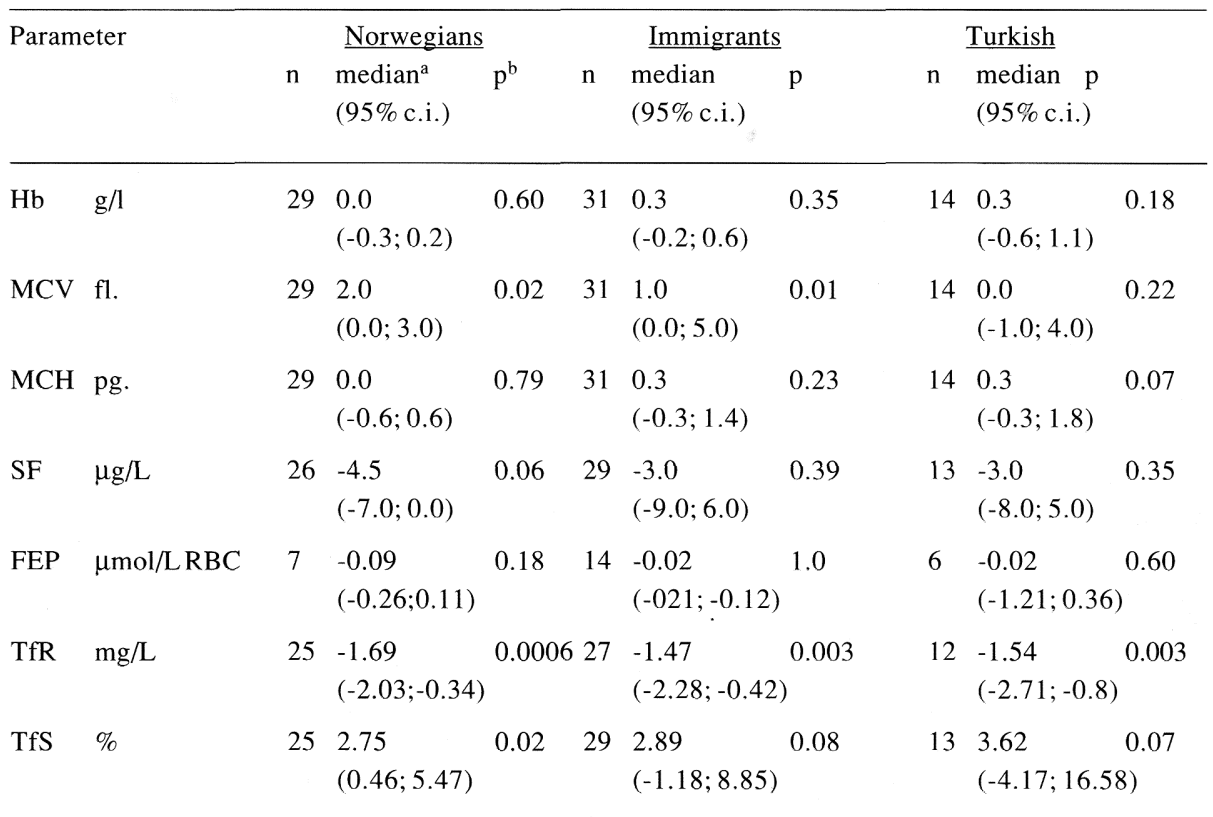

${ }^{a}$ Median and $95 \%$ confidence interval of delta-variables, ${ }^{b}$ Wilcoxon signed-rank test.

next step was to group several variables into an index to have only three categories with approximately $30 \%$ of the observations in each group. The indexes were then crosstabulated with parameters of iron status. Indexes for consumption of food items with enhancing or inhibiting effect were also constructed, but these indexes did not give any contribution in characterising the groups of children. They have therefore not been included in the further analyses and the data is not presented.

SPSS/WIN Statistical program package was used for the statistical analyses. The following non-parametric tests were used: Mann Whitney, Fisher's exact test, Wilcoxon signed-rank test, Spearmans rank correlation, chi square and logistic regression analysis. P-values $<0.05$ were considered significant.

\section{Ethics committee}

The longitudinal study has been approved by an institutional ethics committee

\section{Results}

\section{Iron status}

Indices of iron status among Norwegian and immigrant children, and among the subgroup of Turkish children are shown in Table 1. Medians for FEP and TfR were below and all the other medians were above the cut off points for these indices. There were no significant differences in median values between the groups concerning $\mathrm{SF}$ and $\mathrm{Hb}$. The immigrant children had, however, lower medians for MCV, $\mathrm{MCH}$ and TfS as well as higher values for TfR and FEP.

Table 2 shows the number of children in each group who had depleted, very low or low iron stores, anaemia or iron deficiency anaemia. There was a tendency that more immigrant than Norwegian children had depleted iron stores $(\mathrm{p}=0.07)$, but the differences between the groups were less distinct at two years than at one year of age (19).

When comparing the iron status at one and two years of age (Table 3 ), it appears to be a slight decline in SF in all groups, but the decline was not significant for any of the groups. There was a significant rise in MCV among the Norwegian and immigrant children, a rise in TfS among Norwegians and a decline in TfR in all the groups. There were no differences between the groups in the degree of rise or decline in the different parameters when tested with Mann Whitney test between delta variables.

There was a positive correlation between the SF concentrations at one and two years of age $(r=0.42, p=0.002, n=55)$. Fifty percent of the children with $\mathrm{SF}<10 \mu \mathrm{g} / \mathrm{L}$ 
Table 4. Estimated amounts of certain food items consumed per day among Norwegian $(n=37)$, immigrant $(n=39)$ and the sub-group of Turkish $(n=20)$ children at two years of age.

$\begin{array}{cccc} & \text { Norwegian } & \text { Immigrants } & \text { Turkish } \\ \text { Food item } & \text { median }(25-75 \text { perc }) & \text { median }(25-75 \text { perc }) & \text { median }(25-75 \text { perc })\end{array}$

\begin{tabular}{llll}
\hline Porridges, ml/d & $150(29-200)$ & $125(29-250)$ & $213(42-495)$ \\
Milk, ml/d & $400(300-520)$ & $480(288-734)$ & $325(213-645)$ \\
Orange juice, ml/d & $7(0-200)$ & $57(21-200)^{\mathrm{d}}$ & $100(45-200)^{\mathrm{d}}$ \\
Soft drinks, ml/d & $200(81-336)$ & $114(37-285)^{\mathrm{e}}$ & $107(34-222)^{\mathrm{e}}$ \\
Dark bread, slices/d & $4(2-4)$ & $2(1-3)^{\mathrm{a}}$ & $2(1-3)^{\mathrm{b}}$ \\
White bread, slices/d & $0(0-0)$ & $0(0-0)$ & $0(0-0)$ \\
Liver paté, $^{\mathrm{f}}$ & $1(0.3-1.6)$ & $0(0-0)^{\mathrm{a}}$ & $0(0-0)^{\mathrm{a}}$ \\
Brown whey cheese, $^{\mathrm{f}}$ & $0.3(0-1.0)$ & $0(0-0.4)^{\mathrm{c}}$ & $0(0-0)^{\mathrm{b}}$ \\
Meat cuts $^{\mathrm{f}}$ & $0.1(0-0.6)$ & $0(0-0.1)^{\mathrm{d}}$ & $0(0-0)^{\mathrm{d}}$
\end{tabular}

${ }_{\mathrm{a}} \mathrm{p} \leq 0.0001,{ }^{\mathrm{b}} \mathrm{p} \leq 0.001,{ }^{\mathrm{c}} \mathrm{p} \leq 0.01,{ }^{\mathrm{d}} \mathrm{p}<0.05,{ }^{\mathrm{e}} \mathrm{p}<0,01$ Mann Whitney, different from the Norwegian children, ${ }^{\mathrm{f}}$ amount of slices with food item on bread per day.

at one year still had $\mathrm{SF}<10 \mu \mathrm{g} / \mathrm{L}$ at two years of age and $71 \%$ of the children with $\mathrm{SF} \geq 15 \mu \mathrm{g} / \mathrm{L}$ at one year were still above this cut off point at two years of age. However, $29 \%$ of the children who had SF $\geq 15 \mu \mathrm{g} / \mathrm{L}$ at one year had SF $<15 \mu \mathrm{g} / \mathrm{L}$ at two years of age and $30 \%$ had moved from $\mathrm{SF} \geq 10 \mu \mathrm{g} / \mathrm{L}$ to $\mathrm{SF}<10 \mu \mathrm{g} / \mathrm{L}$.

\section{Dietary aspects at two years of age}

Certain dietary aspects, which we postulated to influence iron status in twoyear-old children, will be reported in the following. There were no significant differences between the groups in the amounts of milk or iron enriched porridges taken per day (Table 4). The Norwegian children ate more dark bread (slices per day) than the immigrant children, and this affected the amounts of bread spreads eaten by the different groups. The Norwegian children had a higher intake of liver paté and brown whey cheese than the immigrant children.

There were no differences between the groups in the frequency of intake of meat, fish or entrails (Table 5). However, the score on the iron-index - which was constructed from the amount of iron in bread and porridges per day, and from the frequency of meat-and/or entrails-containing meals - was slightly higher in Norwegian compared to immigrant children $(p=0.06)$.

An important factor regarding iron status is the amount of vitamin C-rich items in the diet. The Norwegian children ate citrus fruits less often than both the immigrant group as a whole, and the Turkish children (Table 5). They also drank less orange juice than the immigrant group as a whole (Table 4). The median values for the Norwegians, the immigrants and the Turkish children were estimated to be 7,57 and $100 \mathrm{ml} /$ day, respectively. However, there were no differences in intake of vegetables, and the vitamin $\mathrm{C}$ index showed no differences between the groups.

The immigrant children had a higher frequency of intake of rice, bulgur, chapatti and beans/lentils than the Norwegian children. They also had a higher frequency of intake of tea, which may inhibit the absorption of iron. The constructed sugarindex and fat-index were not different between the groups.

Some parameters of the diet were included in multivariate regression analyses, to see if any of them were significantly related to very low iron stores $(\mathrm{SF}<15 \mu \mathrm{g} / \mathrm{L})$. The results of a logistic regression analysis are shown in Table 6 . The dependent variable was the index of iron stores, whether above or below the cut off point of $15 \mu \mathrm{g}$ ferritin/L. The independent variables in the model were 1) the ironrich foods: dark bread, liver paté, brown whey cheese and meat cuts on bread, 2) the absorption enhancing foods: fruit juices, as well as 3 ) foods, which may contribute to iron deficiency through displacement of more iron-rich foods, namely milk, soft drinks, white bread and jam/ marmalade. These variables were entered into the model separately. The logistic model suggested a significant effect of amount of milk and of frequency of consumption of brown whey cheese on iron status in this group of children.

High intake of milk was associated with very low iron stores, and a frequent consumption of brown whey cheese on the bread was associated with $\mathrm{SF}>15 \mu \mathrm{g} / \mathrm{L}$. The results did not indicate any independent effect of nationality (Norwegian/ Turkish/other immigrant) on iron status.

We also tested for correlations between the constructed indexes and iron status at
Table 5. Food frequency patterns among Norwegian (N) $(n=37)$, immigrant (I) $(n=39)$ and the subgroup of Turkish $(T)(n=20)$ children at two years of age.

Food frequency, per cent of children

$\begin{array}{llllll}\text { ST/d } & \text { O/d } & \text { ST/w } & \text { LF } & \chi^{2 *} & \text { Sign. }{ }^{a} p\end{array}$

\begin{tabular}{|c|c|c|c|c|c|c|}
\hline \multicolumn{7}{|l|}{ Rice } \\
\hline $\mathrm{N}$ & 3 & 5 & 32 & 61 & & \\
\hline I & 14 & 17 & 64 & 5 & 39.6 & 0.0000 \\
\hline $\mathrm{T}$ & 10 & 10 & 75 & 5 & 16.9 & 0.0008 \\
\hline \multicolumn{7}{|c|}{ Bulgur } \\
\hline $\mathrm{N}$ & 0 & 0 & 0 & 100 & & \\
\hline I & 14 & 0 & 0 & 86 & 5.9 & 0.02 \\
\hline $\mathrm{T}$ & 30 & 0 & 0 & 70 & 12.7 & 0.0004 \\
\hline \multicolumn{7}{|c|}{ Chapatti } \\
\hline $\mathrm{N}$ & 0 & 0 & 0 & 100 & & \\
\hline I & 7 & 10 & 7 & 76 & 10.3 & 0.02 \\
\hline \multicolumn{7}{|c|}{ Meat } \\
\hline $\mathrm{N}$ & 0 & 11 & 87 & 3 & & \\
\hline I & 5 & 24 & 67 & 5 & 5.1 & 0.2 \\
\hline $\mathrm{T}$ & 0 & 25 & 70 & 5 & 2.4 & 0.3 \\
\hline \multicolumn{7}{|c|}{ Fish } \\
\hline $\mathrm{N}$ & 0 & 0 & 87 & 13 & & \\
\hline I & 0 & 5 & 81 & 14 & 1.9 & 0.4 \\
\hline $\mathrm{T}$ & 0 & 0 & 85 & 15 & 0.03 & 0.8 \\
\hline \multicolumn{7}{|c|}{ Entrails } \\
\hline $\mathrm{N}$ & 3 & 0 & 8 & 90 & & \\
\hline I & 0 & 0 & 13 & 87 & 1.5 & 0. \\
\hline $\mathrm{T}$ & 0 & 0 & 10 & 90 & 0.6 & \\
\hline
\end{tabular}

Beans/lentils

$\begin{array}{lllll}\mathrm{N} & 0 & 0 & 3 & 97\end{array}$

$\begin{array}{lllll}\text { I } & 0 & 2 & 64 & 33\end{array}$

$\begin{array}{lllll}\text { T } & 0 & 5 & 80 & 15\end{array}$

Green vegetables

$\begin{array}{lllll}\mathrm{N} & 0 & 24 & 53 & 24\end{array}$

$\begin{array}{lllll}\text { I } & 5 & 26 & 48 & 21\end{array}$

$\begin{array}{lllll}\mathrm{T} & 0 & 24 & 53 & 24\end{array}$

Vegetables

$\begin{array}{lllll}\mathrm{N} & 0 & 60 & 40 & 0\end{array}$

$\begin{array}{lllll}\text { I } & 7 & 45 & 45 & 3\end{array}$

$\begin{array}{lllll}\mathrm{T} & 5 & 50 & 40 & 5\end{array}$

Citrus fruits

$\begin{array}{lllll}\mathrm{N} & 5 & 18 & 34 & 42\end{array}$

$\begin{array}{lllll}\text { I } & 5 & 51 & 32 & 12\end{array}$

$\begin{array}{lllllll}\mathrm{T} & 5 & 65 & 20 & 10 & 13.5 & 0.004\end{array}$

Tea

$\begin{array}{lllll}\mathrm{N} & 0 & 0 & 27 & 76\end{array}$

$\begin{array}{lllll}\text { I } & 0 & 17 & 26 & 57\end{array}$

$\begin{array}{lllll}\mathrm{T} & 0 & 25 & 35 & 40\end{array}$

7.5

0.02

$12.8 \quad 0.002$

Sweets

$\begin{array}{lllll}\mathrm{N} & 3 & 13 & 74 & 11\end{array}$

$\begin{array}{lllllll}\text { I } & 5 & 10 & 57 & 29 & 4.6 & 0.2\end{array}$

$\begin{array}{lllllll}\text { T } & 10 & 15 & 55 & 20 & 2.9 & 0.4\end{array}$

Bisquits/Cookies

$\begin{array}{lllll}\mathrm{N} & 0 & 11 & 76 & 13\end{array}$

$\begin{array}{lllllll}\text { I } & 7 & 14 & 57 & 21 & 4.8 & 0.2\end{array}$

$\begin{array}{lllllll}\mathrm{T} & 10 & 25 & 55 & 10 & 6.5 & 0.09\end{array}$

Crisps

$\begin{array}{lrrrrrr}\mathrm{N} & 3 & 0 & 55 & 42 & & \\ \mathrm{I} & 2 & 12 & 57 & 29 & 5.6 & 0.1 \\ \mathrm{~T} & 5 & 15 & 45 & 33 & 6.3 & 0.1\end{array}$

a Comparison between Norwegian and immigrant/ Turkish children; ST/d=Several times/day O/d=Once/day: ST/w=Several times/week $\mathrm{O} / \mathrm{d}=$ Once/day: $\mathrm{ST} / \mathrm{w}=$ Several times/we
$\mathrm{LF}=$ Less frequently 
Table 6. Likelihood of having ferritin values above the cut off point of $15 \mu \mathrm{g} / \mathrm{L}$ as a function of intake of different food items at two years of age. A logistic model.

\begin{tabular}{llr}
\hline Food & ${\text { Ferritin }>15^{\text {a }}}^{\text {r }}$ & \\
& & Sign \\
\hline Milk, ml & -0.003 & 0.03 \\
White bread, slices & & $\mathrm{ns}$ \\
Medium dark bread, & & $\mathrm{ns}$ \\
$\quad$ slices & & $\mathrm{ns}$ \\
Dark bread, slices & & $\mathrm{ns}$ \\
Liver paté & & 0.05 \\
Brown whey cheese & \\
Meat cuts on bread & 1.65 & $\mathrm{~ns}$ \\
Goodness of fit: & $\chi^{2 * 10.47, \text { df } 7}$ & \\
& $\%$ predicted 72 &
\end{tabular}

\footnotetext{
*=Chi square

a The following variables were excluded because they did not contribute to improvement of the goodness of fit or discriminating power of the model: soft drinks, fruit juices and marmalade as bread spreads, nationality (Norwegian/Turkish/other immigrant).

b Slices of food item on bread.
}

two years of age. The most consistent correlations found, were between the sugar-index and SF. A high sugar-index score was associated with a low SF in all nationality groups: Norwegians $r=-0.4$, $p=0.04$; immigrants $r=-0.5, p=0.01$; Turkish $\mathrm{r}=-0.7, \mathrm{p}=0.01$. Among Norwegian children a positive correlation between $\mathrm{SF}$ and iron-index $(\mathrm{r}=0.4, \mathrm{p}=0.02)$ was found, i.e., more children with a low score (low iron intake) had SF below $10 \mu \mathrm{g} / \mathrm{L}$.

\section{Discussion}

There are both advantages and disadvantages in performing a study in a limited area and with a small sample size. A small sample size gives the opportunity to examine iron status and aspects of the diet in detail, to have a longitudinal design, and thereby to know more about the study group than would have been possible in a larger study. The same health nurse carried out all the interviews at one and two years of age, the participation rate was high and the factors related to regional differences and variation in health information between primary health clinics can thus be ruled out (19).

A weak point in this study is, however, that we did not have any possibility to measure food intake by direct methods e.g., weight recording. A quantified questionnaire was used and some of the questions were formulated so that the amounts eaten could be estimated from cup/glass sizes, or otherwise from standard weights of bread slices and different spreads (23).
At two years of age probably most of the children were not in their homes during daytime, thus aquiring a detailed picture of their food intake may be difficult. However, most of the children spent their daytime in the kindergarden where the meal patterns are rather standardized.

At one year of age more immigrant than Norwegian infants had depleted iron stores $(\mathrm{SF}<10 \mu \mathrm{g} / \mathrm{L}) ; 14 \%$ vs. $0 \%$, and very low iron stores $(\mathrm{SF}<15 \mu \mathrm{g} / \mathrm{L}) ; 32 \%$ vs. $15 \%$, and median values for $\mathrm{Hb}, \mathrm{MCV}$ and $\mathrm{MCH}$ were also lower in the immigrant group (19). At two years of age the differences in prevalence of values below cut off points for $\mathrm{Hb}$ and $\mathrm{SF}$ were less distinct as is shown in Table 2.

By using CRP $>15 \mathrm{mg} / \mathrm{L}$ as a criterion for exclusion, children with infection and possible infectious anaemia were less likely to be included in the study. Two immigrant children had low values for $\mathrm{Hb}, \mathrm{MCV}, \mathrm{MCH}$ and high TfS values as well as high SF concentration at two years of age. These children may have thalassemia, but were not available for further analyses to set a diagnosis.

The prevalence of anaemia among the Norwegian children at two years of age in our study was similar to findings from two other Nordic studies $(6,24)$. Compared to other European studies of children in similar age groups, our findings are not alarming. Prevalences of depleted iron stores in some other studies are: $57 \%$ with SF below $7 \mu \mathrm{g} / \mathrm{L}$ (22 months old Asian children in Birmingham) (11), $48 \%$ with SF below $10 \mu \mathrm{g} / \mathrm{L}$ (12-24 months old Asian children in Sheffield) (10) and $38 \%$ with SF below $12 \mu \mathrm{g} / \mathrm{L}$ (two-year-old Parisian children) (1). Whereas Hercberg et al. (1) found a rise in iron status between one and two years of age, Duggan et al. (10) found a decline towards the age of two years. Even though the prevalences of low iron status are higher in other European studies than in ours, we observed a slight decline in median values for $\mathrm{SF}$ - which is the first parameter to respond to a negative iron balance - and a rise in TfS from one to two years. However, there were still differences in iron status between Norwegian children and immigrant children at two years of age.

The highly significant decline in TfR from one to two years in all groups were expected since values for TfR have been found to be higher in infants than in older children and adults $(21,25)$. Hence, this decline can not be used as an indication of a better iron status at two years than at one year of age.

Many factors may contribute to higher prevalence of iron deficiency among the immigrant compared to the Norwegian children. One explanation which has been suggested in some studies is differences in dietary practices between immigrant and native children (26), and especially in the intakes of milk and fat-containing foods (13). At one year of age the Norwegian children had a higher frequency of intake of wholemeal bread, liver paté and meat/ fish, whereas the immigrant children had a higher frequency of intake of rice and vegetables. Length of exclusive breastfeeding up to 7 months and the frequency of intake of liver paté were found to be positively related to iron status (19).

At two years of age the Norwegian children still had higher intakes of dark bread and different bread spreads containing a fair amount of iron of high bioavailability, compared to the immigrants. On the other hand immigrant children had higher intake of orange juice, and a more frequent use of citrus fruits which may increase iron absorption. Their contribution is, however, highly dependent on the composition of the meals. The immigrant children also consumed chapatti, beans/ lentils and tea more often. These are all food items which may inhibit iron absorption (28). The size of the iron stores is also an important factor which regulates the iron absorption (29).

The high negative correlation between the constructed sugar-index and SF in the different groups suggests that a high consumption of foods with low nutrient density may be an important contributor to low iron stores in this age group. A high intake of fat and or sugar is also seen in other studies $(13,18,30)$. Some of the studies also showed a rather low intake of iron $(1,13,18,31)$. This is in line with results from a 2 x 48 hour recall performed among six of the Norwegian children at two years of age. Iron intake was between 4.0 and $7.2 \mathrm{mg} / \mathrm{d}$. Three of the six children had a sugar energy percent higher than the recommended maximum of $10 \%$, and two of these were above $20 \%$ (unpublished data). Hay (9) found the same results in her study among 44 healthy Norwegian two-year-old children. In Uldall's study (13) intakes of sweets and soft-drinks were higher among immigrant than among native children, and this may have had an effect on iron status. There was a significantly higher intake of these food items in children with iron deficiency anaemia compared to non-anaemic children.

In our study there were no significant differences in consumption of milk between the groups, but in the logistic regression model (Table 6), high intake of milk was associated with very low iron stores $(\mathrm{SF}<15 \mu \mathrm{g} / \mathrm{L})$. In the same model there was a positive relationship between high intakes of brown whey cheese and SF above $15 \mu \mathrm{g} / \mathrm{L}$. The absorption of iron 
from this iron supplemented cheese is good (27). Interestingly, nationality was excluded very early from the model. This means that nationality does not play any independent role for the differences in iron status in this study.

The problem of low iron status related to different feeding regimens during the first year of life is well recognized (3237). The results from the present study suggest that more attention should be

\section{References}

1. Hercberg S, Papoz L, Gal·n P, Guery MF, Farnier MA, Rossignol C: Iron status and dietary pattern in young children. Nutr Reports Int 1987;35:307-15.

2. Walter T: Effect of iron-deficiency anaemia on cognitive skills in infancy and childhood. Baillieres Clin Haematol 1994; 7: 815-27.

3. Lozoff B, Jimenez E, Wolf AW: Long-term developmental outcome of infants with iron deficiency. New Eng J Med 1991:325:687-91.

4. Idjradinata P,PollittE: Reversal of developmental delays in iron-deficient anaemic infants treated with iron. Lancet 1993;341:1-4.

5. Major P: Jernmangelanemi og spedbarns psykomotoriske utvikling. (Iron deficiency anaemia and psychomotor development in infants.) Tidsskr Nor Lægeforen 1994;114:1995-6.

6. Nilsen BR, Moe PJ: Hematologiske verdier hos barn fra fødsel til 16 års alder. Tidsskr Nor Lægeforen 1979;99:214-6.

7. Aspelund F: Hb-unders $ø$ kelse av ett-åringer ved helsestasjoner. Tidsskr Nor Lægeforen 1977;29: 1519.

8. Bærug A: Kosthold, jernstatus og infeksjoner hos spedbarn. M. Sc. Thesis. Institute for Nutrition Research, University of Oslo, Norway, 1987.

9. Hay G: Jernstatus og jerninntak hos norske toåringer. M.Sc. Thesis. Nordic School of Nutrition, University of Oslo, Norway, 1995.

10. Duggan MB, Steel G, Elwys G, Harbottle L, Noble C: Iron status, energy intake, and nutritional status of healthy young Asian children. Arch Dis Child 1991:66:1386-9.

11. Grindulis $\mathrm{H}, \mathrm{Scott} \mathrm{PH}$, Belton NR, Wharton BA: Combined deficiency of iron and vitamin $\mathrm{D}$ in Asian Toddlers. Arch Dis Child 1986;61:843-8.

12. Erhardt I: Iron deficiency in young Bradford children from different ethnic groups. $\mathrm{Br}$ Med J 1986;292:90-3.

13. Uldall P, Jensen J, Petersen R, Christensen KM: Ernæringsproblemer i småbørnealderen II. Småbørnskosten hos indvanderbørn og danske børn med og uten jernmangelanæmi. Ugeskr Læger 1984;146:567-70. directed to children's diet and iron status in the second and probably third years of life. Dietary information and education is very important also during this period to secure a shift to a varied diet with high iron bioavailability.

\section{Acknowledgements}

We are most grateful to Heidi Vikan and Marit Dramdal and interpreters at Fjell
Health Clinic without whose cooperation and enthusiasm this study would not have been possible. We thank Louise K Dahll and Randi Waage at the Central Laboratory, Buskerud Central Hospital for carrying out the biochemical analyses and Torfinn Hansen, Cederroth A/S, Oslo, Norway, for help with statistical analyses. This study was in part supported by a grant from Aktieselskabet Freia Chocolade Fabriks Medicinske Fond, 1992.
14. Brunvand L, Sander J: Jernmangelanemi hos innvandrerbarn fra utviklingsland. Tidsskr Nor Lægeforen 1993;113:1719-20.

15. Sørensen E: Innvandrerbarn i sykehus. Tidsskr Nor Lægeforen 1989;109:1377-80.(English summary)

16. Statens ernæringsråd. Anbefalinger for spedbarnsernæring 1993. (Norwegian Nutrition Council. Recommendations for infant nutrition 1993)

17. Kjærnes U, Botten G, Lande B, Nilsson D: Food intake and patterns of feeding of Norwegian infants. Eur J Clin Nutr 1988;42: 249-60.

18. Kylberg E: Diets of healthy Swedish children 4 24 months old. Ph. D. Thesis. Department of Pediatrics, University Hospital. Uppsala 1986.

19. Wandel M,Fagerli RAa, Olsen PT, Borch-Iohnsen $\mathrm{B}, \mathrm{EkJ}$ (1995): Iron status and weaning practices among Norwegian and immigrant infants. Nutr Res 1996;16(2): 251-65

20. Dallman PR: Iron. In: Brown ML, ed. Present knowledge in Nutrition. 6. ed. Washington D.C.: International Life Sciences Institute - Nutrition Foundation 1990: 241-50.

21. Olivares M, Walter T, Cook JD: Age-related changes in serum transferrin receptor values. XV International Congress of Nutrition, Adelaide (Australia), abstr. p. 7211993

22. National Academy of Science: Iron deficiency anaemia: Recommended guidelines for the prevention, detection and management among U.S. children and women of childbearing age. US National Academy Press. Washington D.C., U.S.A. 1993.

23. Mål og vekt for matvarer. Landsforeningen for kosthold og helse 1989.

24. Jansson LT, Kling S, Dallman PR: Anemia in children with acute infections seen in a primary care pediatric outpatient clinic. Pediatr Infect Dis 1986;5:424-7.

25. Thorstensen K, RomsloI: The transferrin receptor: its diagnostic value and its potential as therapeutic target. Scand J Clin Lab Invest 1993;53 (suppl 215):113-120.
26. Uldall P, Jensen J, Petersen R, Christensen KM: Ernæringsproblemer i småbarnealderen I. Tyrkiske og Pakistanske småbørns næringsstofindtagelse og ernæringsstatus. Ugeskr Læger 1984;146:563-6.

27. Borch-Iohnsen B, Bakkene G, Ekman M, Reizenstein P: High bioavalability to humans of supplemental iron in a whey concentrate product. Nut Res 1994;11:1643-8.

28. Bothwell TH, Baynes RD, Mac Farlane BJ, Mac Phayl AP: Nutritional iron requirements and food iron absorption. J Internal Med 1989;226:357-65.

29. Cook JD, Lipschitz DA, Thiles LEM, Finch CA Serum ferritin as a measure of iron status in normal subjects. Am J Clin Nutr 1974; 27: 681-7.

30. Rossow I, Kjærnes U, Holst D: Patterns of sugar consumption in early childhood. Community Den Oral Epidemiol 1990;18:12-6.

31. Harbottle L, Duggan MB: Daily variation in food and nutrient intakes of Asian children in Sheffield Eur J Clin Nutr 1994;48:66-70.

32. Calvo EB, Galindo AC, Aspres NB: Iron status in exclusively breast-fed infants. Pediatrics 1992;90:375-9.

33. Penrod JC, Anderson K, Acosta PB: Impact on iron status of introducing cow's milk in the second six months of life. J Pediatr Gastr Nutr 1990;1 0:462-7.

34. Pizarro F, Yip R, Dallman PR, Olivares M, Hertrampf E, Walter T: Iron status with differen infant feeding regimens: relevance to screening and prevention of iron deficiency. J Pediatr 1991; 118:687-92

35. Olivares M, Walter T, Hertrampf E, Pizarro F Stekel A: Prevention of iron deficiency by milk fortification. The Chilean experience. Acta Pædiatr Scand Suppl 1989;361:109-13.

36. Tunnessen WW, Oski FA: Consequences of starting whole cow milk at 6 months of age. J Pediatr 1987;111:813-6.

37. Siimes MA, Salmenpera L, Perheentupa J: Exclusive breast-feeding for 9 months: risk of iron deficiency. J Pediatr 1984; 104:196-9. 